\title{
Thoughts on the Regulation of Content on Social Media in Latin America: Authors' Rights, Limitations and Content Filtering
}

Maria L. Vazquez, Maria Carolina Herrera Rubio, Alejandro Aréchiga Morales

Abstract: The array of issues involved in the regulation of social media, and their cardinal importance in Latin America - from privacy, freedom of expression, liabilities, disinformation, right to erasure, and copyright - is compelling, yet staggering in its expanse and substance. This review is not meant to be exhaustive, but it does provide thoughts and selected examples on the regulatory framework of social media content in Latin America. The first part of this paper aims to give an overview of some of the more noteworthy developments regarding internet and social media regulations in certain countries. Then, the analysis will focus on authors' rights in Latin America, analyzing how successfully - or not - traditional exceptions and limitations of international copyright law regulate copyrighted content on social media.

Keywords: Social Media, Latin America, Copyright, Limitations, Content, Filtering, Regulation

\section{Chapter 1. Introduction}

Determining what the regulation of social media content is in Latin America and how it is enforced is a constant challenge. The array of relevant issues, and their cardinal importance in the region - from privacy, freedom of expression, liabilities, disinformation, right to erasure, and copyright - is compelling, yet staggering in its expanse and substance.

With the noteworthy exception of Brazil's Marco Civil of the Internet passed in 2014, a pioneer law regarding the protection of fundamental rights and principles on the Internet, Latin American countries do not 
have specific regulations for social networks, ${ }^{1}$ yet it could be said that there is a perception among policymakers in the region that the online space remains under-regulated. ${ }^{2}$ The lack of understanding as to how content moderation works in Latin America, among other reasons, has led to increasing calls from both governments and civil society, for regulation against major platforms. ${ }^{3}$

Nevertheless, with over 410 million users of social media ${ }^{4}$ in Latin America, legal controversies arise and courts have relied on classic civil law rules to decide on matters regarding defamation lawsuits and invasion of privacy.

This review was not meant to be, and clearly could not be, exhaustive. The first part of this paper aims to give an overview of selected developments regarding the regulation of social media content in some countries of Latin America, while mentioning the type of traditional norms that are applied to the digital environment. Then, the analysis will narrow in on copyright in Latin America, and how statutory exceptions and limitations regulate copyrighted content on social media. The analysis seeks to address whether the present copyright regulatory framework is suitable to the digital environment. Finally, content moderation on social networks in Latin America shall be briefly discussed, with specific attention to the new notice and takedown procedures introduced in the 2020 Mexican Federal Copyright Law.

Chapter 2. The Latin American landscape of social media governance: A brief overview of regulations in México, Colombia, Argentina and Chile

Latin America is a region with deep economic and social inequalities. In this context, access to information and communication technologies serves as a possible tool to attain social inclusion and achieve the region's

1 Andrés Calderón, "Moderate Globally Impact Locally: Content Moderation in Social Media in Latin America: A promise to consumers", Yale Law School Information Society Project, October 27, 2020, https://law.yale.edu/isp/initiatives/wikimedia-initi ative-intermediaries-and-information/wiii-blog/moderate-globally-impact-locally-co ntent-moderation-social-media-latin-america-promise-consumers.

2 Augustina del Campo, "Social media in Latin America: Caught between a rock and a hard place”, Global Voices, September 17, 2020, https://globalvoices.org/2020/09/1 7/social-media-in-latin-america-caught-between-a-rock-and-a-hard-place/.

3 N.N., "Social media in Latin America."

4 Simon Kemp, "Digital 2020 July Global Statshot", we are social. July 21, 2020, https://wearesocial.com/blog/2020/07/digital-use-around-the-world-in-july-2020. 
development goals. However, though there are important differences from country to country, according to data from the Development Bank of Latin America (CAF), 38\% of the region's population does not have internet access. ${ }^{5}$ Thus, the inequalities of the region are also present in its digital ecosystem.

Adding to that, "Internet use in much of Latin American households is limited to communication tools and social networks." 6 This falls in line with the report that Facebook and Whatsapp are the principal news sources in Argentina, Brazil, Chile, and Mexico. ${ }^{7}$ In 2019, Latin American users top the global rank of most time spent in social media, with an average of 212 minutes a day. ${ }^{8}$

Evidently, a comprehensive legal framework to regulate social media is due. However most Latin American countries have not included provisions that directly regulate social media platforms into their domestic legal systems.

Before providing a general layout of the different rules that inform the different domestic legal systems of Latin American countries in this subject, it is important to make an approximation of how social networks are defined in Latin America. Currently, there is a bill in Mexico, proposed by Senator Ricardo Monreal Avila, that defines "social media services" as the "internet services that have the main function of sharing content published by users, in the form of texts, data, voice notes, images, video, music, sounds or a combination of these, with the purpose of informing, entertaining or educating audiences."

5 "Transformación digital para la América Latina del S. XXI", Banco de Desarrollo de América Latina, accessed June 22, 2021, https:/www.caf.com/es/conocimiento/v isiones/2020/02/transformacion-digital-para-la-america-latina-del-s21/.

6 Carlos I. Ortuño, "COVID-19 and digital inclusion in Latin America and the Caribbean: A connectivity and access problem", SELA. Latin American And Carribean Economic System, June 04, 2020, http://www.sela.org/en/press/articles/a/6448 8/covid-19-digital-inclusion-in-latin-america-and-the-caribbean.

7 Observacom, "Redes sociales son las principales vías de acceso a la información en América Latina”, Observatorio Latinoamericano de Regulación de Medios y Convergencia, June 22, 2020, https://www.observacom.org/redes-sociales-son-las-principales-vi as-de-acceso-a-la-informacion-en-america-latina/

8 Fernando Duarte, "Los países en los que la gente pasa más tiempo en las redes sociales (y los líderes en América Latina)”, BBC News Mundo, September 9, 2019, https://www.bbc.com/mundo/noticias-49634612.

9 Iniciativa con proyecto de Decreto por el que se REFORMAN y ADICIONAN diversas disposiciones de la Ley Federal de Telecomunicaciones y Radiodifusión, Senador Dr. Ricardo Monreal Ávila, Morena Political Party, Mexico. 
It is important to point out that social networks bring together a diversity of users, from the private and public sector, and these actors communicate a variety of social, political and/or commercial interests. Thus, legislation drafted to intervene these spaces must be in balance with this breadth of protagonists and functionalities.

This section shall point out advances made in the regulatory frameworks of México, Colombia, Argentina and Chile regarding some of the major issues which arise in relation to social media platforms. These issues are: (a) Liability of Internet Intermediaries, (b) Protection of personal data and privacy, (c) Right to honor and reputation, and (d) Legal trends related to hate speech and influencers. Regulation of copyrighted content in social media will be addressed in Section 3.

\section{Chapter 2.a. Intermediary Liability}

As far as online intermediaries are concerned, liability standards have been set in the region, though none comparable to Section 230 of the U.S. Communications Decency Act. Before going over the laws and rulings that have informed the intermediary liability systems in some Latin American countries, it is convenient to briefly define the terms "strict liability" and "subjective liability". Strict liability arises from the damages caused to a third party in the exercise of an activity considered to be risky, regardless of whether the conduct was carried out negligently or with harmful intent. Instead, when subjective liability rules are applied, the focus is on the accused's intention, knowledge or awareness to determine, on a case-by-case basis, if the acts were originated in ignorance or negligence. Thus, a strict liability regime entails a greater demand on the conduct of internet intermediaries; even when unaware of the commission of the reproached behaviors, they shall, nonetheless, be responsible by virtue of their activities as providers of internet services.

\section{a) MEXICO}

In Mexico, there is not a specific law regulating intermediary liability. However, last year's modification to the Federal Copyright Law, proposes a limitation to their responsibility in relation with the circulation of content protected by authors' rights. This Law exonerates the "online service providers" from liability for the infringement of intellectual property 
rights, under the condition that they proceed to withdraw this content once they have been notified of the existence of the infringing content by the owner of the protected works or an authorized representant or ordered to remove it by a competent authority ${ }^{10}$.

\section{b) COLOMBIA}

Colombia's current legal framework provides no specific law concerning exclusively with intermediary liability. Nonetheless, Law 679 of 2.001 set liability standards for intermediaries, in relation to the exhibition of child pornography through global networks of communication. Following are the main points of the aforementioned law:

- The national government must promote the adoption of autoregulation systems ${ }^{11}$ for persons and enterprises located in Colombia, whose main commercial activity is the trade of goods and services using global networks of information ${ }^{12}$.

- The law prohibits providers, administrators, and users of global networks of information, from: (i) hosting pornographic material of minors on their own websites; (ii) hosting explicit material in which the participants could be believed to be minors and, (iii) hosting links to websites that distribute such material ${ }^{13}$.

- Failure of an intermediary to denounce, contend and take down such content or using networks of communication in the manner prohibited by the Law ${ }^{14}$ will generate fines (up to 100 minimum legal wages) and the cancelation or suspension of infringing websites ${ }^{15}$, plus prison charges.

Given the gaps in Colombia's regulatory framework, courts have filled in the blanks (a repeated pattern in the region). Following are the points

10 Article 114, Octies, Ley Federal Del Derecho De Autor, Congreso De Los Estados Unidos Mexicanos, 2020.

11 Article 6, Law 679, 2001, Congress Republic of Colombia.

12 Article 3, Law 679, 2001, Congress Republic of Colombia.

13 Article 7, Law 679, 2001, Congress Republic of Colombia.

14 Article o 8, Law 679, 2001, Congress Republic of Colombia.

15 Article 10, Law 679, 2001, Congress Republic of Colombia. 
of analysis observed by Colombia's Constitutional Court in two rulings relevant to the subject at hand, cases T-277/15 ${ }^{16}$ and SU420/19 ${ }^{17}$ :

- In case T-277/15, the Court refers to the Joint Declaration on Freedom of Expression and the Internet, adhering to its principle of "mere transmission", meaning that no person or enterprise who exclusively provides technical Internet services shall be held responsible for the content created by third parties. After recognizing the role of the Intermediaries as catalysts for the free traffic of ideas, the Court concludes that holding the Intermediaries responsible for the illicit doings in user-generated content would affect the communicative exercise in the digital space "because it would give them the power to regulate the flow of information in the Web".

- In case SU420/19, the Court confirms its position regarding the absence of liability of intermediaries for content created by platform users. However, it considers that during the legal proceedings carried out in defense of the rights of honor and reputation, if the user who has uttered the reproved expressions is absent, the intermediary must participate as a third party as, eventually, it will have to follow the judges content removal order.

\section{c) ARGENTINA}

Once again, given the lack of specific legislation, when addressing issues related to intermediary liability, Argentine judges have drawn upon the general principles of civil and criminal liability.

One of the most relevant cases in Argentina's jurisprudence is that of "Rodriguez Maria Belen c/ Google. Inc". ${ }^{18}$ María Belén Rodríguez, an Argentine entertainment personality, brought a civil case against Google, seeking damages as a result of having her name and images associated to websites with explicit content. The first ruling found Google responsible for having infringed the rights of the plaintiff, awarding the latter compensation for

16 Sentencia de tutela Radicado No. T-277/15, 2015, Corte Constitucional, Colombia. https://www.corteconstitucional.gov.co/relatoria/2015/t-277-15.htm

17 Sentencia de Unificación Radicado No. SU420/19, 2019, Corte Constitucional, Colombia. https://www.corteconstitucional.gov.co/relatoria/2019/SU420-19.htm

18 Rodríguez, María Belén c. Google Inc. s. daños y perjuicios, 2014, Corte Suprema de Justicia de la Nación, Argentina. https://cdh.defensoria.org.ar/normativa/rodri guez-maria-belen-c-google-inc-s-danos-y-perjuicios/ 
damages and ordering the removal of the links. During the appeal, the previous judgment was partially annulled, in this instance, the National Appeals Chamber of Argentina found that there was no evidence that the defendant refused to take down the offensive content after being notified of its existence.

Finally, the case reached the Supreme Court, which displayed a comparative analysis of legal precedents from several countries from which it generated the following conclusions:

- When applying civil rules to cases where a fundamental right is at risk, these laws are to be interpreted in the way that better adapts to the National Constitution.

- If intermediaries do not have a general duty to monitor the content, they cannot be held responsible for the content generated by users, thus rejecting a strict liability standard on the basis of the threat it would pose to free expression rights.

- When the conducts of intermediaries are examined in a judicial procedure, the judge must use the rules of subjective liability. Intermediaries shall be accountable for the damages caused to third parties only when they had "effective knowledge" of the commission of the illicit behavior and did not respond accordingly.

- When the conduct is not clearly transgressive to the rights of honor and image of the user who is denouncing it, that is when it is not a case of "gross and manifest harm", the court held that search engines could not be liable for unlawful content upon notification unless a public authority had adjudicated the material as unlawful.

- Google Image thumbnails were considered links and not Google's own content.

A recent case involving former president, and current vice-president Cristina Fernandez de Kirchner, also received much news coverage. The case to be decided is the lawsuit filed by the vice-president against Google for defamation and tarnishing of her image, name, and honor, based on the fact that when entering her name into Google's search engine, instead of mentioning her position in the government, there appeared an epithet reading "Thief of the Argentine Nation". The result did not refer to any third-party website but was under the sole responsibility of Google.

As a preventive measure, the plaintiff filed a petition with the court demanding that Google preserve the data related to her name for inspection in the proceedings. This request was granted by both the Civil Judge and the appellate court after the defendant appealed the first decision. Google presented a complaint to Argentina's Supreme Court against the appellate 
court's ruling; however, this was overruled in March $2021 .{ }^{19}$ This case may set an important precedent as to the way evidence is handled in cases relating to acts of defamation on the internet.

\section{d) CHILE}

In Chile, the intellectual property regime was modified by Law 20,435, which includes a chapter on the liability of intermediaries. Intermediaries are not forced to monitor the content generated by users, thus releasing them from liability in this regard, on the condition, the intermediary abides by the rules of article $85 \mathrm{~N}$ of said law.

The mentioned article applies to providers of search and linking services and providers that, at the request of the user, host data in their systems, stating that these subjects are freed of liability if they:

- Do not have effective knowledge of the illicit data;

- Do not profit from the infringing conduct;

- Appoint an agent to receive the judicial notices of the existence of the illicit content;

- Expeditiously remove the material considered to be infringing. ${ }^{20}$

On its part article $85 \mathrm{U}$ of the law in question, devises a "notice to notice to notice"21 system, meaning that when an intermediary has received the notices of the allegedly infringing content, they must inform the creator or owner of said content, briefing them on the facts of the notice.

\section{Chapter 2.b. Personal Data Protection}

Regulating social media policies regarding personal data is essential, being that users expose their personal and domestic life, revealing information that can be easily exploited against their interests, thereby undermining their rights to privacy. Latin American countries have been mindful of this

19 Patricia Blanco, "La Corte Suprema falló a favor de Christian Kirchner en la causa que inició contra Google”, infobae, March 19, 2021, https:/www.infobae.com/pol itica/2021/03/19/la-corte-suprema-fallo-a-favor-de-cristina-kirchner-en-la-causa-que -inicio-contra-google/.

$2085 \tilde{N}$, Ley 20.435, 2010, Congreso Nacional, Chile.

21 85U, Ley 20.435, 2010, Congreso Nacional, Chile. 
need and Data Protection Laws in the region have proliferated through the last decade.

a) $\mathrm{MEXICO}$

The Mexican Law on Protection of Personal Data in the Private Sector was passed in 2010, and the General Law on the Protection of Personal Data Possessed by Obligated Subjects was passed in $2017 .{ }^{22}$

\section{b) COLOMBIA}

In 2012, the Colombian congress passed Statutory Law 1581, which regulates the treatment and protection of personal data collected in the Colombian territory and the data collected elsewhere, by a person who is obligated to comply with Colombian law by virtue of international treaties $^{23}$.

\section{c) ARGENTINA AND CHILE}

Argentina and Chile have the oldest laws in the continent and currently, both are pending updating. For Argentina, this is Law 25.326 of 2000 and for Chile, Law 19.628 of $1999 .^{24}$

\section{Chapter 2.c. Rights to Honor and Reputation}

Defamation is a criminal offense in the penal codes of certain Latin American countries.On the international stage, the Inter-American Human Rights Court has established that the need to repair a defamed person's right is not a justification to restrict freedom of expression prima facie. This

22 Paulina Bojalil, "Despuntan las reformas en materia de protección de datos en América Latina”, ABIERTA al público (blog), February 12, 2019. https://blogs.iadb. org/conocimiento-abierto/es/proteccion-de-datos-gdpr-america-latina/.

23 Artículo 2, Ley Estatutaria 1581, 2012, Congreso de República de Colombia.

24 Valentina Hernández Bauzá, Sucesos regulatorios en materias de privacidad e internet en Latinoamérica (Derechos Digitales América Latina, 2020), https://www.derecho sdigitales.org/wp-content/uploads/tendencias-privacidad-latam.pdf. 
means that to define which right should prevail between the right to honor or the right to free speech, the court must take into account the specifics of each case. This exercise implies engaging in a proportionality judgment, in which prior censorship must be prevented, this was expressed by the mentioned tribunal in the Kimel case, which will be further explained later.

\section{a) MEXICO}

Mexico is an example of decriminalization of defamatory offenses within the Latin American context. Since the reform of the Federal Criminal Law in 2007, insult, slander, and defamation are considered illegal acts, instead of criminal offenses, generating liability via civil law. ${ }^{25}$

\section{b) COLOMBIA}

In Colombia's legal system, defamation is still penalized by criminal law. As of July 2020, a new bill, ${ }^{26}$ which regulates defamation and other related offenses against honor, reputation, privacy and image, gives the victims of such acts the prerogative of filing for reparation through in civil courts as well.

\section{c) ARGENTINA}

Argentina’s Law № 26.551 allows all forms of expression when they concern matters of public interest ${ }^{27}$. This legislation was prompted by the case Kimel vs Argentina, ${ }^{28}$ a relevant precedent for the entire human rights system in Latin America, and a milestone in defamation cases in Argentina,

25 La Relatoría Especial Para La Libertad De Expresión. (2013, noviembre 11). Comunicado de Prensa R 85/13, https:/www.oas.org/es/cidh/expresion/showarticle.a sp?artID=934\&IID $=2$

26 L. 48, 2020, Gaceta No. 593 del Congreso de Colombia.

27 Artículo 5, Ley 26.551, 2009. Congreso de la Nación Argentina.

28 Kimel V. Argentina, 2008. Sentencia de Fondo, Reparaciones y Costas. Corte Interamericana de Derechos Humanos. 
which began progressively removing the prison penalties for slander and defamation from its penal code ${ }^{29}$.

Kimel, a journalist, writer, and investigative historian published "The San Patricio Massacre ("La Masacre de San Patricio), a book on his investigation of the murder of five people from a religious order during Argentina's military dictatorship, criticizing how the authorities handled the judicial procedures that followed. In 1991, the State brought criminal proceedings against Kimel for defamation of a judge criticized in the book. Upon the conclusion of the criminal proceedings, he was convicted of libel and sentenced to one-year imprisonment and payment of a large sum in damages.

The Inter-American Court of Human Rights found that the State violated the American Convention on Human Rights. The importance of this decision lies in its very precise restatement establishing that speech regarding public officials acting in the course of their duties, and the public interest, enjoys a greater degree of protection. The ruling provides a proportionality analysis between the judge's right to reputation and Kimel's right to free speech, with a three-part test regarding the degree to which each right was affected, the importance of each right, and the existing justifications to restrict one right and satisfy the other. It also emphasized the need to scrutinize very carefully when using criminal law to restrict freedom of expression.

\section{d) CHILE}

The victim of defamation and slander may file for reparations in civil or criminal courts, as these offenses are also part of the Chilean penal code, punishable by prison sentences and fines. However, according to Law 19.733, personal opinions relating to political, literary, historic, artistic, scientific, technical and sports subjects" expressed in "social communication media" are not considered slander, as long as there is not intent to insult. ${ }^{30}$

29 La Relatoría Especial Para La Libertad De Expresión. (2013, noviembre 11). Comunicado de Prensa R 85/13, https:/www.oas.org/es/cidh/expresion/showarticle.a sp?artID=934\&lID $=2$.

30 Article 29, Law 19.733, Congreso de Chile. 


\section{Chapter 2.d. Other Regulatory Trends}

\section{a) Hate speech}

The exercise of free speech is the cornerstone of social and political interactions on the internet. Due to this dynamic, trying to regulate hate speech may cause unintended negative effects on freedom of expression.

At the regional level, the American Convention on Human Rights (The Pact of San José), protects freedom of expression in its article $13,{ }^{31}$ refusing to consider hateful national, racial or religious speech, that incites to commit a violent act, as a legitimate manifestation of this right. In the Latin American region, with the exception of Bolivia and Venezuela ${ }^{32}$, there are no domestic laws that directly prohibit or regulate hate speech in the digital sphere.

According to Human Rights Watch ${ }^{33}$, the political climate around freedom of expression in Mexico is going through a worrying situation due to the previously mentioned draft bill of legislation, authored by Senator Ricardo Monreal Avila, that seeks to reform the federal law on telecommunications and broadcasting. One of the most criticized points of this bill is the ample faculties given to the Federal Telecommunications Institute (IFT). In order to operate in Mexico, digital platforms must present their terms and conditions before the IFT, agreeing to limit the dissemination of hate speech. The bill, however, does not define what should be considered as a hateful message. Said bill grants the IFT the ultimate decision powers in the challenges presented by users regarding the decisions to cancel accounts and remove content made by the platforms.

Argentine law on hate crimes is based mainly on the Anti-Discrimination Act, Law No. 23592 of 1988. Currently in Argentina there is a bill ${ }^{34}$ referring to this subject, in which hate speech is defined as the messages or expressions that "intimidate, discriminate or incite hatred or violence against based on motives of race, religion, nationality, gender, sexual orien-

31 Convencion Americana Sobre Derechos Humanos (Pacto De San José), 1969. Organización de Estados Americanos. Artículo 13.

32 Rodrigo Vargas Acosta, Sucesos regulatorios en materias de libertad de expresión e internet en Latinoamérica (Derechos Digital América Latina, 2020), https://www.de rechosdigitales.org/wp-content/uploads/tendencias-regulacion-digitales.pdf.

33 Human Rights Watch, "Mexico: Online Free Speech at Risk," April 14, 2021, https://www.hrw.org/news/2021/04/14/mexico-online-free-speech-risk

34 Proyecto de Ley 848/20. Senado De La Nación. Argentina. https://www.senado.go b.ar/parlamentario/comisiones/verExp/848.20/S/PL 
tation, disability, among others". The same law urges platforms to follow a procedure for receiving complaints in which the denounced publications are temporarily withdrawn.

\section{b) The legal regulation of influencers}

Given that "influencers", protagonists of social media, tend to play a role in consumer choices and behaviors, many countries have tried to regulate the exercise of this activity.

Mexico $^{35}$ and Colombia have not dictated laws to control influencers. However, in Colombia ${ }^{36}$, the Superintendency of Industry and Commerce, issued a guide of best advertising practices for influencers, seeking to create transparency between them, their sponsors, and consumers. Argentina ${ }^{37}$, on its part, has a new bill proposing to regulate influencers as "digital advertisers", with mandatory disclosure of their sponsoring contracts with sponsors, and consumer protection regulations as to the disclosure of information and contraindications of the advertised products. Finally, although Chile does not have a law directed to influencers, they are regulated through tax laws. ${ }^{38}$

35 Luis Mario Lemus Rivero, "Influencers, aspectos legales a considerar", Foro Jurídico, October 8, 2020, https://forojuridico.mx/influencers-aspectos-legales-a-consider ar/.

36 Superintendencia de Industria y Comercio de Colombia. (2020, October 1). Superindustria expide "Guía de buenas prácticas en la publicidad a través de influenciadores.” Sic.Gov.Co. https://www.sic.gov.co/slider/superindustria-expide-“gu\%C3 \%ADa-de-buenas-prácticas-en-la-publicidad-través-de-influenciadores

37 Paula Fernandes Pfizenmaier, “Influencers' Regulation In Argentina: When No Law Is Better Than A Bad Law”, Mondaq, 16 July, 2020, https://www.mondaq.co $\mathrm{m} /$ unitedstates/socialmedia/965950/influencers39-regulation-in-argentina-when-n o-law-is-better-than-a-bad-law.

38 Marcela Gómez, Matías Bobadilla, "Influencers deben pagar impuestos por ganancias en redes sociales", pauta.cl, March 28, 2021, https://www.pauta.cl/ec onomia/influencers-tributacion-impuestos-chile-redes-sociales. 
Chapter 3. Intellectual Property Laws in the context of Social Media Platforms in Latin America: Regulating Copyrighted Content in Latin America

As discussed, the regulation of social media platforms is, as of yet, a matter of unfinished public policy in Latin America. Although there are a few ad hoc norms in force in some countries, the regulatory framework for social media platforms is still emerging, with the region struggling to apply current regulations to channel the legal questions arising from interactions on social networks. ${ }^{39}$

As far as the regulation of copyright in Latin America is concerned, each country has its particular legislations and guidelines to prevent the unauthorized use of works. Most of the provisions have been harmonised with the copyright protection criteria established in international treaties, as shall be addressed herein.

Furthermore, all Latin American countries provide for limitations and exceptions within their copyright frameworks to allow certain unlicensed uses of copyrighted materials. To ensure that the legitimate interests of rights holders are respected, laws typically include limitations restricting such content from being used for commercial purposes or from interfering in the original work's market.

Two things to keep in mind: First, limitations and exceptions do not waive the author's moral rights (such as the right of authorship, the right of integrity of work and the right of divulgation). Second, continuous technological progress keeps creating new possibilities for uses of copyrighted works, yet the same legislations are applied to regulate the new uses. Very few countries have adapted their copyright laws specifically to the digital environment.

\section{Chapter 3.a. Overview of the Copyright System in Latin America and its Exceptions and Limitations}

Although the term "copyright" is often used in reference to authors' rights in Latin America, it is important to point out that Latin American countries follow the model of the continental legal system, rooted particularly

39 Moisés Sánchez, Informe sobre control estatal de redes sociales (Alianza Regional por la Libre Expresión e Información, 2016), http://www.alianzaregional.net/wp-cont ent/uploads/Informe-Arti\%CC\%81culo-XIII-2016-GF-SR-DM.pdf. 
in French law. As such, the essence is that, in addition to the economic rights that the law grants to authors of literary, artistic or scientific works, the droit d'auteur legal system grants authors moral rights, related to the "paternity", integrity and disclosure of the works. These two sets of rights -moral and economic- are characteristic of the "continental" vision (droit d'auteur), in contrast to the Anglo-Saxon vision (copyright), where the moral component has not been incorporated until rather recently, and perhaps with little enthusiasm. ${ }^{40}$

As mentioned, authors' rights in Latin America have been harmonised, thanks to the international treaties and multilateral conventions. The Berne Convention is the oldest of these conventions, dating from 1886. ${ }^{41}$ Therein, the region adheres to the principle of automatic protection of works, which establishes that works will be protected from their creation $^{42}$, without the need for registration or any formality. The only condition is that the work is captured in a fixed medium and has a minimum of originality.

\section{a) Background: Berne and the Three-Step Rule}

The main concern of authors when the Berne Convention was adopted in the late $19^{\text {th }}$ century, ${ }^{43}$ was to avoid the improper appropriation or reproduction of their works by third parties. In the absence of a harmonized or uniform international system for the recognition of copyright, plagiarism

40 J. Carlos Fernández-Molina and Eduardo Peis, "The moral rights of authors in the age of digital information", Journal of the American Society for Information Science and Technology 52, issue 2, (2001): 109-117, https://doi.org/10.1002/1097-4571(200 0)9999:9999\%3C::AID-ASI1060\%3E3.0.CO;2-B.

41 In addition to this, there are other international instruments in those that have established standards for the protection of copyright and related rights and that have contributed to the consolidation of a uniform international system, such as the Rome Convention 1961, the Phonograms Convention of 1971, the Convention on the distribution of signals satellite channels of 1974, the World Intellectual Property Organization (WIPO) Copyright Treaty of 1996 (WCT) and the WIPO Performances and Phonograms Treaty of 1996 (WPPT).

42 See article 5, paragraph 2 of the Berne Convention.

43 "Reseña del Convenio de Berna para la Protección de las Obras Literarias y Artísticas", Organización Mundial de la Propiedad Intelectual, accessed June 22, 2021, https://www.wipo.int/treaties/es/ip/berne/summary_berne.html\#: :text=El\% 20Convenio $\% 20 \mathrm{de} \% 20$ Berna $\% 20$ trata,que $\% 20$ quieran $\% 20$ valerse $\% 20 \mathrm{de} \% 20$ ellas. 
or unauthorized use of works was a constant risk. ${ }^{44}$ Berne gave authors, musicians, poets, painters, among others, the means to control who used their works, how and under what conditions. At the same time, it served to establish the minimum standards of international protection for literary and artistic works.

When setting these international rules for the recognition and protection of copyright, it was also made clear that countries could limit the protection of a work or allow the exceptional use of literary or artistic works without the consent of their author. These provisions are known as copyright limitations and exceptions. ${ }^{45}$

Among the most common limitations set by the Berne Convention are the following:

(i) the limitation on the protection of official texts ${ }^{46}$,

(ii) the limitation on protection of daily news and press information ${ }^{47}$,

(iii) the limit on protection of political speeches and those in legal proceedings ${ }^{48}$.

On the other hand, in relation to exceptions, we have:

(i) the right to use citations or the right to quote (in educational and other particular circumstances $)^{49}$;

(ii) the use for teaching purposes ${ }^{50}$;

(iii) the use of articles in newspapers and periodical collections ${ }^{51}$;

44 Prior to the adoption of the Berne Convention, there were national laws historical relevance that recognized and protected copyright, such as, the "Statute of Anne", the original title of which is "An act for the encouragement of learning, by vesting the copies for printed books in the authors or purchasers of such copies, during times there in mentioned", passed in 1709. Other countries joined this wave of copyright protection; in 1790 the United States enacted its first copyright law; In 1791 and 1793 France approved Decrees 13 and 19 on the protection of literary works, and finally, in Spain, 1847 (Christian Schmitz Vaccaro, "Evolución de la regulación internacional de la propiedad intelectual," (Concepción, Chile: Universidad Católica de la Santísima Concepción, 2013) https://revistas.uexternad o.edu.co/index.php/propin/article/view/3580/3661).

45 Limitations and exceptions are based on Article 9 (2) of the Berne Convention.

46 See article 2.4 Berne Convention.

47 See article 2.8 Berne Convention.

48 See article 2 bis 1 Berne Convention.

49 See article 10.1 Berne Convention.

50 See article 10.2 Berne Convention..

51 See article 10bis 1 Berne Convention.. 
(iv) the use of works in information relating to current events; 52 and

(v) the use of information from conferences, speeches and other similar events. 53

The interpretation criteria for these limitations and exceptions are based on what is commonly known as the three-step rule introduced in article 9.2 of the Berne Convention: "It shall be a matter for legislation in the countries of the Union to permit the reproduction of such works in certain special cases, provided that such reproduction does not conflict with a normal exploitation of the work and does not unreasonably prejudice the legitimate interests of the author."

These three factors, which has become central in international conventions relating to copyright, is the basis of interpretation establishing the limits of permissible uses of works of third parties. Though the Berne Convention established this rule referring only to the right of reproduction, through the Agreement on Trade-Related Aspects of Intellectual Property Rights (TRIPS) ${ }^{54}$, this rule was extended to any of the exclusive rights related to copyright. ${ }^{55}$

Exceptions and limitations are an important part of any copyright system, allowing creators to access and continue creating, using the knowledge generated by others. Without exceptions and limitations, the authors' rights system would not be able to achieve at least one of its fundamental purposes, which is to stimulate creation and promote innovation for the benefit of humanity. ${ }^{56}$ The background described shows that there is a broad regulatory system related to the protection of copyright, not only in Latin America, but in the world, that serves as a fundamental framework for the unauthorized use of content on the internet.

52 See article 10bis 2 Berne Convention.

53 See article 2bis.2 Berne Convention..

54 See article 13 TRIPS.

55 "La regla de los tres pasos," Electronic Frontier Foundation, accessed June 22, 2021, https://www.eff.org/sites/default/files/filenode/tpp_3pasos.pdf.

56 Gwen Hinze, "Hacer que el conocimiento sea accesible a través de las fronteras: excepciones mínimas obligatorias de derechos de autor internacionales para la educación,” Electronic Frontier Foundation, October 30, 2008, https://www.eff.org/ wp/making-knowledge-accessible-across-borders-case-ma. 
b) Authors' rights in copyrighted content from the user's standpoint: Are everyday practices of social media content-sharing illegal in Latin America? Is copyright affecting essential tasks on the internet and limiting social practices of democracy, such as access to culture and information?

As is commonly known, the use of the internet in general, and social networks in particular, has generated practices that are based on the creation of content, or the reproduction, re-use or transformation of third -party content. Sometimes these dynamics imply obtaining a direct or indirect profit. Some examples are the creation of memes, sharing GIFs, those unavoidable loops of animation, or retweeting the status of another user, uploading stories to social networks such as Instagram or Twitter in which third-party songs are incorporated and the streaming of e-sport games on platforms such as Twitch or YouTube.

Thus, while a user of social media platforms is potentially the author of copyright--protected content, he or she, in turn, is a possible infringer of copyrights that belong to third parties.

In this context, one considers whether these dynamics carried out on the internet are adequately regulated by the same principles that apply to activities carried out in our analog, offline environment. Are our Latin American droit d'auteur laws outdated?

Most scholars in Latin America agree that local copyright laws can be applied to content in social networks, although not specifically mentioned in the norms, when such content fulfills copyrightability standards, such as originality.

To cite an example, several scholars have maintained that though Law 11,723, the main legal provision on authors' rights in Argentina, is almost one hundred years old, its broad wording, complemented with the international treaties to which Argentina is a party, allow it to achieve a comprehensive copyright protection applicable in the digital age. ${ }^{57}$

Other authors like Busaniche, consider that Law 11,723 regulates copyright through a highly restrictive model that, consequently, curtails circulation and makes common practices of socialization of culture illegal, affecting essential tasks and social practices of democracy, such as access to culture and information, the work of teachers and students and their

57 Carlos A. Villalba and Delia Lipszyc, El derecho de autor en la Argentina (Ciudad Autónoma de Buenos Aires, Argentina: La Ley 2009); Ariel Alberto Neuman, "Derechos de autor y era digital", El Cronista, June 6, 2018, https://www.cronista.c om/legales/Derechos-de-autor-y-era-digital-20180606-0011.html. 
access to educational materials, and the work of libraries. She argues that in today's digital environments, this system, in which the conditions that gave meaning to copyright are completely modified, needs a structural transformation. ${ }^{58}$

It is important to clarify that using or reproducing third-party content is not always illegal. As mentioned, limitations and exceptions are a fundamental part of the copyright system, and allow the use and disclosure of content, provided the use is deemed permissible under the three-step rule.

Yet, in order to permit the aforementioned socialization of culture, when thinking about copyright rules in the digital era, we must pay as much attention to addressing limitations and exceptions, as to enhancing copyright protection. Are the existing limitations and exceptions to copyright in Latin America suitable to permit the regular interactions taking place on today's social media? More importantly, what about the access to culture and circulation of information in the digital environment? It does not seem clear that many of these acts will be permissible under the present limitations and exceptions system, which has a very narrow and limited scope.

As user-generated content flourishes, Elkin-Koren argues that users play a critical role in copyright law, and makes a fascinating case for the "user rights approach". 59 Observing the user's interests only through the spectacles of limitations and exceptions, is far too narrow, and overlooks the vital role users play in the copyright system. Elkin-Koren makes the thought-provoking suggestion that permissible uses under copyright law should be articulated and treated as rights.

58 Beatriz Busaniche, "Argentina Copyleft. La crisis del modelo de derechos de autor y las prácticas para democratizar la cultura”, Fundación Via Libre, September 10, 2010, https://www.vialibre.org.ar/argentina-copyleft-la-crisis-del-modelo-de-derech os-de-autor-y-las-practicas-para-democratizar-la-cultura/.

59 Niva Elkin-Koren, "Copyright in a Digital Ecosystem: A User-Rights Approach", Forthcoming in RUTH OKEDIJI, COPYRIGHT IN AN AGE OF LIMITATIONS AND EXCEPTIONS, July 28, 2015, https://ssrn.com/abstract=2637027. 
c) Should exceptions and limitations in Latin America be reformed in order to adapt to the common practices in the digital environment? Is there a possibility of incorporating broader criteria, such as the Copyright Fair Use factors?

Questions arise as to how to adapt our Latin American authors' rights frameworks to better suit the digital environment.

Limitations to authors' rights in the laws of Latin American countries are lists of very specifically defined, and narrowly constructed exceptions to the exclusivity granted to authors by law. These are exhaustive, closed lists; if a use of copyrighted content does not fall into one of these very specific categories, it will be considered an infringement. In contrast, the four statutory factors of fair use in U.S, copyright law, and the fifth factor of "transformative use" introduced by courts, provide more flexible criteria that can be used by courts to decide whether a specific use is permissible on a case-by-case basis.

The idea of adopting the Fair Use interpretation criteria has not, as of yet, been a viable alternative for Latin American countries. There is a certain fear of the unpredictability associated with the application of the fair use criteria, and the traditional rule in countries, including those of the European and Latin America, is that copyright limitations and exceptions must be narrowly defined.

Nevertheless, it is surprising that the international three-step test, which has been incorporated into Latin American legislations through the adoption of the Berne Convention as well as other treaties, is in fact rooted in the Anglo-American copyright tradition. ${ }^{60}$

It has often been considered that the three-step test in international copyright law is is an obstacle to the adoption of more flexible criteria at the national level, yet, Geiger, Gervais \& Senftleben have considered that the test was actually intended to serve as a more flexible balancing tool, offering national policy makers the possibility to adopt a flexible system of limitations and exceptions. ${ }^{61}$

60 Christophe Geiger, Daniel J. Gervais and Martin Senftleben, "The Three-Step-Test Revisited: How to Use the Test's Flexibility in National Copyright Law", (November 18, 2013) American University International Law Review, Vol. 29, No. 3 (2014), pp. 581-626, https://ssrn.com/abstract=2356619 or http://dx.doi.org/10.2139/ssrn.2 356619

61 Christophe Geiger, Daniel J. Gervais and Martin Senftleben. "The Three-Step-Test Revisited: How to Use the Test's Flexibility in National Copyright Law", American University International Law Review 29 no. 3 (2014):581-626. 
Among the treaties signed by many Latin American nations are the WIPO Copyright Treaty (WCT) and the WIPO Performances and Phonograms Treaty (WPPT). In order to consider the possibility of Latin American countries to reform their legislations regarding limitations and exceptions, it is particularly noteworthy to highlight certain provisions of the WIPO Copyright Treaty and its "Agreed Statements". The details of these treaties is beyond the scope of this overview, but suffice it to mention that some provisions therein, indicate quite specifically that the function of the three-step test is to serve as a flexible framework for the adoption of limitations and exceptions at the national level.

Article 10(1) of the WCT is a direct application of the three-step test to WCT rights:

"Contracting Parties may, in their national legislation, provide for limitations of or exceptions to the rights granted to authors of literary and artistic works under this Treaty in certain special cases that do not conflict with a normal exploitation of the work and do not unreasonably prejudice the legitimate interests of the author."

The Agreed Statement Concerning Article 10 WCT states: ${ }^{62}$

"It is understood that the provisions of Article 10 permit Contracting Parties to carry forward and appropriately extent into the digital environment limitations and exceptions in their national laws which have been considered acceptable under the Berne Convention. Similarly, these provisions should be understood to permit Contracting Parties to devise new exceptions and limitations that are appropriate in the digital network environment. It is also understood that Article 10(2) neither reduces nor extends the scope of applicability of the limitations and exceptions permitted by the Berne Convention."

This statement is between all parties to the WCT, prepared at the same time as the Convention, which makes it an important context for the interpretation of article 10 .

62 Sam Ricketson, "WIPO Study on Limitations and Exceptions of Copyright and Related Rights in the Digital Environment”, March 3, 2008. 


\section{Chapter 3.b. Notice and Take-Down: Content Filtering in Latin America}

In order to protect copyright online, notice and take-down procedures and content filtering systems work in tandem, allowing the copyright owner to request the removal of the infringing content, while the filtering systems serve to ensure that the offending content does not re-upload on the internet. Systems such as these are provided for in the U.S. DMCA, ${ }^{63}$ implemented in 1998 and the Directive of the European Union ${ }^{64}$ of 2000.

In Latin America, many have argued that in practice these systems have been used to generate acts of censorship of opponents, as tools to control reputation and public image, as well as to manipulate or modify the publicly accessible information that is hosted on the internet. ${ }^{65}$ All of the above, based on the filing of claims for alleged invasions of copyright online. ${ }^{66}$ For example, in Ecuador, some years back, copyright laws were used to remove content criticizing the government. ${ }^{67}$

The creation of these systems has close ties to the creation of the WIPO internet treaties (WCT) and (WPPT) in 1996. As mentioned, most countries in Latin America are party to the WIPO treaties (WCT and WPPT), which establish the obligation to have effective measures to avoid the execution of infringing actions on the internet.

In Chile these mechanisms were established through Law 20,435 of $2010 .{ }^{68}$ In Costa Rica through Regulation 36880-COMEX-JP of 2011 and in Paraguay through Law 4,868 of Electronic Commerce of $2013^{69}$ and more recently in Mexico with the reforms to the Federal Copyright Law of 2020.

63 See https://www.law.cornell.edu/uscode/text/17/512

64 «Directiva sobre el comercio electrónico 2000/31/CE.» 2000. https://eur-lex.europ a.eu/legal-content/ES/TXT/HTML/?uri=CELEX:32000L0031\&from=ET (accessed: 2021).

65 Reseña del Tratado de la OMPI sobre Derecho de Autor (WCT) (1996)," Organización Mundial de la Propiedad Intelectual“, accessed June 22, 2021, https://www. wipo.int/treaties/es/ip/wct/summary_wct.html.

66 Alejandro Aréchiga Morales, "Sistema de notificación y retirada en México: los derechos en juego", Centro de Política Digital para América Latina, 2021 .

67 Derechos Digitales, "The various paths of Internet censorship in Latin America", IFEX, November 14, 2014, accessed 10 July, 2021, https://ifex.org/the-various-path s-of-internet-censorship-in-latin-america/.

68 See Article 14 WCT and Article 23 WPPT, Provisions on Enforcement of Rights.

69 Rodrigo Vargas Acosta, "Responsabilidad de intermediarios por infracciones a los derechos de autor en Chile, Paraguay y Costa Rica: Un análisis desde la libertad de expresión", Revista chilena de derecho y tecnología, Vol. 5, no. 1 (2016), https://do i.org/10.5354/0719-2584.2016.41782. 


\section{a) The particular case of the new law in Mexico}

A particular case study in Latin America is that of the new Mexican Federal Copyright Law. In response to the United States-Mexico-Canada Agreement (USMCA in the US, T-MEC in Mexico) which took effect on July 1, 2020, the Mexican government reformed its intellectual property legislation, including amendments to its Federal Copyright Law, effective July 2, 2020.

Among the provisions that were amended, is the addition of a notification and withdrawal system that enables Mexican Internet users to file claims when they consider that their copyright is affected by a third party. ${ }^{70}$

The implementation of the notification and withdrawal system generated concern among interested parties, with several civil organizations publicly arguing that these measures affect the exercise of other rights on the internet, for example, freedom of expression, access to culture or information. ${ }^{71}$

Among the main criticisms that the notification and withdrawal system received are the speed with which the reform was approved, due to the pressure to comply in time with the commitments and negotiations derived from the T-MEC. Likewise, the effects that it can generate on the exercise of other rights on the Internet and the errors with which it was incorporated into the LFDA were criticized.

Naturally, the reform was defended by the government and other interested parties. Discussions on the legality of the system by the academic sector and media became more compelling when the National Commission of Human Rights (CNDH), an autonomous constitutional body of Mexico, filed a claim of unconstitutionality before the Supreme Court of Justice of the Nation (SCJN) on the grounds that the notification and withdrawal system may affect the exercise of fundamental rights on the internet. $^{72}$

70 Consult articles 114 septies and octies of the Federal Law of Copyright of Mexico http://www.diputados.gob.mx/LeyesBiblio/pdf_mov/Ley_Federal_de_Derechos.p $\mathrm{df}$

71 "Red de defensa de los derechos digitales. Ni censura ni candados", R3D, accessed June 22, 2021 https://participa.nicensuranicandados.org/.

72 Consult Action of Unconstitutionality 217/2020, https://www.cndh.org.mx/tipo/2 09/accion-de-inconstitucionalidad?field_fecha_creacion_value $\% 5 \mathrm{Bmin} \% 5 \mathrm{D}=\&$ fiel d_fecha_creacion_value $\% 5 \mathrm{Bmax} \% 5 \mathrm{D}=\& \mathrm{keys}=217 \% 2 \mathrm{~F} 2020 \&$ items_per_page $=10$. 
In addition, in the action of unconstitutionality, the Supreme Court pointed out deficiencies, errors and omissions with which the system was incorporated into the Federal Copyright Law. This claim has not yet been resolved.

\section{Chapter 4. Conclusion}

In a region with glaring economic and political inequalities such as Latin America, digital transformation will have a strong impact on inclusiveness, and social media can provide empowerment and, help shape users to progress socially, economically, educationally, and politically.

When the state gives companies more faculties to moderate content, greater control of the public debate falls on the private sector. Yet, is it counterproductive that content can only be moderated if the state allows it? There are models of moderation in online communities, where users decide what kind of content should be filtered, based on the interest of maintaining a healthy dialogue. Ideally, companies could maintain a certain flexibility to decide what content to allow on their platform, but with clear and transparent rules. A social media platform should have to report to the user the reasons a certain expression is being restricted, and there should be appeal mechanisms. Regulation would have to focus on making the exercise of that power accountable.

The challenge for Latin America will be to provide regulation for these activities, whilst crafting rules that safeguard freedom of expression, appropriate to each country's particular domestic social, legal and political contexts, while securing privacy and facilitating civic and social engagement.

\section{Bibliography}

"Reseña del Convenio de Berna para la Protección de las Obras Literarias y Artísticas” Organización Mundial de la Propiedad Intelectual, accessed June 22, 2021, https:/www.wipo.int/treaties/es/ip/berne/summary_berne.html\#: :text=El\%20C onvenio\%20de $\% 20$ Berna $\% 20$ trata,que $\% 20$ quieran $\% 20$ valerse $\% 20 \mathrm{de} \% 20$ ellas.

«Directiva sobre el comercio electrónico 2000/31/CE.» 2000. https://eur-lex.europa .eu/legal-content/ES/TXT/HTML/?uri=CELEX:32000L0031\&from=ET (último acceso: 2021).

Alejandro Aréchiga Morales. "Sistema de notificación y retirada en México: los derechos en juego,” Centro de Política Digital para América Latina, 2021. 
Banco de Desarrollo de América Latina. "Transformación digital para la América Latina del S. XXI.” Accessed June 22, 2021. https://www.caf.com/es/conocimient o/visiones/2020/02/transformacion-digital-para-la-america-latina-del-s21/.

Bojalil, Paulina. "Despuntan las reformas en materia de protección de datos en América Latina.” ABIERTA al público (blog), February 12, 2019. https://blogs.iad b.org/conocimiento-abierto/es/proteccion-de-datos-gdpr-america-latina/.

Convencion Americana Sobre Derechos Humanos (Pacto de San José), 1969. Organización de Estados Americanos. Articulo 13.

Duarte, Fernando. "Los países en los que la gente pasa más tiempo en las redes sociales (y los líderes en América Latina).” BBC News Mundo, September 9, 2019. https://www.bbc.com/mundo/noticias-49634612.

Electronic Frontier Foundation. "La regla de los tres pasos." Accessed June 22, 2021. https://www.eff.org/sites/default/files/filenode/tpp_3pasos.pdf.

Fernández-Molina, J. Carlos and Peis, Eduardo. "The moral rights of authors in the age of digital information." Journal of the American Society for Information Science and Technology 52, issue 2, (2001): 109-117. https://doi.org/10.1002/1097-4571(20 00)9999:9999\%3C::AID-ASI1060\%3E3.0.CO;2-B.

Gómez, Marcela and Bobadilla, Matías. "Influencers deben pagar impuestos por ganancias en redes sociales.” pauta.cl, March 28, 2021. Pfizenmaier, P. F. (2020, July 16). Influencers' Regulation In Argentina: When No Law Is Better Than A Bad Law. Mondaq.Com. https:/www.mondaq.com/unitedstates/social-media/96595 0/influencers39-regulation-in-argentina-when-no-law-is-better-than-a-bad-law

Hernández Bauzá, Valentina. Sucesos regulatorios en materias de privacidad e internet en Latinoamérica. Derechos Digitales América Latina, 2020. https://www.derecho sdigitales.org/wp-content/uploads/tendencias-privacidad-latam.pdf.

Hinze, Gwen. "Hacer que el conocimiento sea accesible a través de las fronteras: excepciones mínimas obligatorias de derechos de autor internacionales para la educación.” Electronic Frontier Foundation, October 30, 2008. https://www.eff.org /wp/making-knowledge-accessible-across-borders-case-ma.

Human Rights Watch. "Mexico: Online Free Speech at Risk." April 14, 2021. https://www.hrw.org/news/2021/04/14/mexico-online-free-speech-risk

LA RELATORÍA ESPECIAL PARA LA LIBERTAD DE EXPRESIÓN. (2013, November 11). Comunicado de Prensa R 85/13.

Lemus Rivero, Luis Mario. "Influencers, aspectos legales a considerer.” Foro Jurídico, October 8, 2020. https://orojuridico.mx/influencers-aspectos-legales-a-conside rar/\#: :text=Para\%20comenzar\%2C\%20es\%20importante\%20hacer,Ley\%20Fede ral\%20de\%20Radio\%20y.

Ley 20.435, 2010. Congreso Nacional, Chile.

Ley 26.551, 2009. Congreso de la Nación Argentina, Articulo 5.

Ley 48, 2020. Gaceta del Congreso No. 593, Colombia.

Ley 679, 2001. Congreso de República de Colombia, Capitulo II: Del uso de redes globales de información en relación con menores, Colombia.

Ley Estatutaria 1581, 2012. Congreso de República de Colombia. Artículo 2. 
Ley Federal Del Derecho De Autor, 2020, Congreso De Los Estados Unidos Mexicanos, Artículo 114 Octies, México.

Ley Federal Del Derecho De Autor, 2020, Congreso De Los Estados Unidos Mexicanos, Artículo 114 Octies, México.

Moisés Sánchez. Informe sobre control estatal de redes sociales (Alianza Regional por la Libre Expresión e Información, 2016), http://www.alianzaregional.net/wp-conte nt/uploads/Informe-Arti\%CC\%81culo-XIII-2016-GF-SR-DM.pdf.

Observacom. "Redes sociales son las principales vías de acceso a la información en América Latina." Observatorio Latinoamericano de Regulación de Medios y Convergencia, June 22, 2020. https:/www.observacom.org/redes-sociales-son-las-princip ales-vias-de-acceso-a-la-informacion-en-america-latina/

OMPI. GUIA SOBRE LOS TRATADOS DE DERECHO DE AUTOR Y DERECHOS CONEXOS. s.f.

Organización Mundial de la Propiedad Intelectual. Reseña del Tratado de la OMPI sobre Derecho de Autor (WCT) (1996). s.f. https://www.wipo.int/treaties/es/ip/w ct/summary_wct.html (último acceso: 10 de 04 de 2021).

Ortuño, Carlos I. "COVID-19 and digital inclusion in Latin America and the Caribbean: A connectivity and access problem." SELA. Latin American And Carribean Economic System, June 04, 2020. http://www.sela.org/en/press/articles/a/64 488/covid-19-digital-inclusion-in-latin-america-and-the-caribbean.

Proyecto de Ley 848/20. Senado De La Nación. Argentina.

R3D. "Red de defensa de los derechos digitales. Ni censura ni candados." Accessed June 22, 2021. https://participa.nicensuranicandados.org/.

Rodrigo Vargas Acosta. "Responsabilidad de intermediarios por infracciones a los derechos de autor en Chile, Paraguay y Costa Rica: Un análisis desde la libertad de expression.” Revista chilena de derecho y tecnología, Vol. 5, no. 1 (2016). https://doi.org/10.5354/0719-2584.2016.41782.

Rodríguez María Belén c. Google Inc. s. daños y perjuicios, 2014, Corte Suprema de Justicia de la Nación, Argentina.

Sam Ricketson. "WIPO Study on Limitations and Exceptions of Copyright and Related Rights in the Digital Environment," March 3, 2008. Accessed June 22, 2021. https://www.wipo.int/edocs/mdocs/copyright/en/sccr_9/sccr_9_7.pdf.

Schmitz Vaccaro, Christian. "Evolución de la regulación internacional de la propiedad intellectual." (Concepción, Chile: Universidad Católica de la Santísima Concepción, 2013). https://revistas.uexternado.edu.co/index.php/p ropin/article/view/3580/3661.

Senador R. M. Ávila, Iniciativa con proyecto de Decreto por el que se REFORMAN y ADICIONAN diversas disposiciones de la Ley Federal de Telecomunicaciones y Radiodifusión, Partido Morena, México. https://ricardomonrealavila.com/wp-con tent/uploads/2021/02/REDES-SOCIALES-Propuesta-Iniciativa-29.01.21.pdf

Sentencia de tutela Radicado No. T-277, 2015, Corte Constitucional, Colombia. https:/www.corteconstitucional.gov.co/relatoria/2015/t-277-15.htm 
Sentencia de Unificación Radicado No. SU420/19, 2019, Corte Constitucional, Colombia. https://www.corteconstitucional.gov.co/relatoria/2019/SU420-19. htm

Superintendencia de Industria y Comercio de Colombia. (2020, October 1). Superindustria expide "Guía de buenas prácticas en la publicidad a través de influenciadores." Sic.gov.co. https://www.sic.gov.co/slider/superindustria-expide-0\%E2\%80 \%9Cgu\%C3\%ADa-de-buenas-pr\%C3\%A1cticas-en-la-publicidad-trav\%C3\%A9s -de-influenciadores\%E2\%80\%9D

Vargas Acosta, Rodrigo. Sucesos regulatorios en materias de libertad de expresión e internet en Latinoamérica. Derechos Digital América Latina, 2020. https://www.d erechosdigitales.org/wp-content/uploads/tendencias-regulacion-digitales.pdf. 
